\title{
THE MEDIATING EFFECT OF ORGANIZATIONAL LEARNING IN THE RELATIONSHIP BETWEEN ENTREPRENEURIAL ORIENTATION AND SOCIAL CAPITAL: EVIDENCE FROMTUNISIA
}

\author{
Nawres MLIKA ${ }^{1}$ and Amel DAKOUMI HAMROUNI ${ }^{2}$ \\ ${ }^{1} \mathrm{PhD}$ Student in Entrepreneurship, Faculty of Economic Sciences and Management of Tunis- Tunisia \\ Research Laboratory ERMA, University of Tunis El Manar Tunisia \\ ${ }^{2}$ Associate Professor in Entrepreneurial marketing, University of Sousse- Higher Institute of Management \\ of Sousse- TunisiaResearch Laboratory ERMA, University of Tunis El Manar Tunisia
}

DOI: 10.46609/IJSSER.2021.v06i04.006 URL: https://doi.org/10.46609/IJSSER.2021.v06i04.006

\begin{abstract}
This research investigates the mediation process and shows how each dimension of the social capital (SC) either -structural, cognitive and relational- affects entrepreneurial orientation through organizational learning. This study was conducted on 235 Tunisian firms. The results of the empirical analysis indicate that only the cognitive dimension of the social capital has a positive and a significant effect on the entrepreneurial orientation (EO), and that the mediating effect of organizational learning in this relationship is insignificant as it remains partial. Thus, organizational learning partially leads the cognitive social capital to enhance a firm's entrepreneurial orientation. Therefore when actors share the same vision, culture and goals, they can avoid any potential misunderstandings in their communication, they are able to exchange ideas, resources, and information. This means they proactively seize opportunities favoring the creation of new creative products and services while being more inclined to take risks.
\end{abstract}

Keywords: Entrepreneurial Orientation, Social Capital, Organizational Learning, Mediating effect, Business Strategy.

\section{Introduction}

Despite a growing number of studies focused on the strength of the Entrepreneurial Orientation (EO) -performance link, the gap is still prevalent in empirical research on the antecedents of (EO).Wales \& al (2020) underline the importance of studying the factors which explain the organizational genesis or sustenance of EO (Wales \& al 2016; De Clercq, Dimov and Thongpapanl , 2013; Kyrgidou and Spyropoulou, 2013). As a matter of fact, many authors emphasize the importance of studying the effect of social capital (SC) on entrepreneurial 


\section{International Journal of Social Science and Economic Research}

ISSN: $2455-8834$

Volume:06, Issue:04 "April 2021"

orientation (OE) (Stam and Elfring, 2008; Wales, Gupta, and Mousa, 2013). EO is defined as the strategic posture of a business that captures the decision-making methods, practices and styles that managers use to act in an entrepreneurial manner (Lumpkin and Dess, 1996). EO is the firm's tendency to act in an entrepreneurial manner. While Social Capital is perceived as the set of current and potential resources available to a company through its network of relationships (Nahapiet and Ghoshal,1998). In order to understand better the effect of social capital on entrepreneurial orientation, we have introduced organizational learning as an explanatory factor in this relationship. We define organizational learning (OL) as a social process of interactions producing new knowledge and new skills. Learning is a cognitive and a heuristic process of understanding and creativity that operates ina new schema of knowledge (Ingham, 1994). While examining the literature on entrepreneurship, we noticed a gap, as there is no academic research that deals with the theoryof social capital, entrepreneurial orientation and organizational learning all together in the Tunisian context. Hence the importance of conducting such a study and further investigate this issue with a view of solving the problem.

The present study contributes to theory in two critical ways. First, it enriches the theory on the antecedents of entrepreneurial orientation by suggesting that social capital (SC) has an impact on the development of a business strategy based on entrepreneurial orientation. Second, the analysis provides deeper insights into the process of how each dimension of SC affects the mediating variable which is OL and also the dependent variable which is EO.

The article is structured as follows. First, it reviews the relevant literature for EO,SC and OL before developing hypotheses on how the different OL dimensions are mediated by SC to affect the development of OE. Next, it describes the research design of the empirical study. Thereafter, the results of the study are presented, followed by a discussion of the data, and concludes with the limitations of the study and suggestions for future research.

\section{Theory and hypotheses}

\subsection{Entrepreneurial orientation}

Henry Mintzberg (1973) is one of the first researchers to recognize the importance of creating an entrepreneurial organizational strategy. According to him, it is through the active search for new opportunities in uncertain environments that significant growth can be achieved. The notion of an entrepreneurial firm did not gain the attention of researchers until after Miller's (1983) publication in which he defines the entrepreneurial company as a firm that "engages in innovation in the product market, undertakes somewhat risky projects and which is the first to offer" proactive "innovations beating the competitors". Entrepreneurial orientation is therefore the will of a company to innovate, that is to adopt and support new ideas, innovations, 


\section{International Journal of Social Science and Economic Research}

ISSN: $2455-8834$

Volume:06, Issue:04 "April 2021"

experiments and creative processes likely to generate new products, services or technological processes, to be proactive by taking the initiative, and to try to shape the environment to its advantage(Lumpkin and Dess, 1996) and "take the risk of facing large and risky resource commitments, i.e those that have a reasonable chance of costly failures" (Miller and Friesen,1978). Based on this definition, the researchers identified three essential dimensions of EO which are: risk taking, innovativeness and proactivity (Barringer and Bluedorn, 1999; Naman and Slevin, 1993; 1999, Wiklund and Shepherd, 2003, 2005, Zahra and Covin, 1995).

However, Lumpkin and Dess (1996) argue that entrepreneurial orientation consists of five dimensions, not just three, they conceptualize competitive aggressiveness and autonomy as two additional dimensions of EO and define autonomy as "the independent action of an individual or a team to bring out an idea or a vision and bring it to fruition" and they define competitive aggressiveness as the propensity of a company to directly and intensely challenge its competitors in order to access the market or improve its position, that is to say, to outperform its competitors in the market" (Lumpkin and Dess, 1996).

Although the conceptual work of Lumpkin and Dess (1996) broadened the construction of EO, for the current study, we adopt the conceptualization proposed by Miller (1983) and we choose the innovativeness, risk taking and proactivity as the dimensions of EO.

\subsection{Social capital}

Companies rise from an original idea, whether from an individual or a collective source. However, the development of this idea can only be achieved through a large number of formal and informal interactions between several actors. Bourdieu (1986), one of the first authors who was interested in studying the social capital, defines it as "The aggregate of current or potential resources which are linked to a lasting network of relations, more or less institutionalized from mutual recognition". Burt (1992) defines it as "Friends, colleagues, and more generally contacts through which you receive opportunities to use your financial and human capital". According to Nahapiet and Ghoshal (1998) social capital is "The sum of the current and potential resources incorporated, available and derived from the network of relationships that individual or social units possess"

Social capital's dimensions are the structural, cognitive and relational dimension (Nahapiet and Ghoshal, 1998). The structural dimension refers to the overall structure of the networkthat a person has (Burt, 1992). It refers to the network of relationships that the actor possesses and his ability to establish weak and strong ties with actors belonging to the same social structure (Hair et al.,2013). The main aspects of the structural dimension are: firstly, the network links, i.e. the way in which the actors are linked in terms of strength, frequency of exchange and close 


\section{International Journal of Social Science and Economic Research}

ISSN: $2455-8834$

Volume:06, Issue:04 "April 2021"

relations, and secondly the configuration of the network, which determines the type of connections between its members in terms of density, connectivity and hierarchy (Parra-Requena et al., 2010).

The relational dimension of SC refers to the nature of interpersonal relationships between individuals. It is about analyzing the type of the links that have been created between actors within a social network. According to Nahapiet and Ghoshal (1998) the relational dimension of SC concerns the types of personal relationships that people have developed through a history of interactions (Granovetter, 1992). The main aspect of this dimension is trust, which refers to the conviction that other network actors will not act opportunistically (Nahapiet and Ghoshal, 1998; Tsai \& Ghoshal, 1998).

The cognitive dimension of SC is embodied in attributes such as a code, a language or a paradigm shared between the members of a social network which facilitates the understanding and the common meaning of the collective objectives and the appropriate ways of acting between them. According to Leana and Pil (2006) "The shared vision and goals and the collective values that underpin them, promote integration and create a sense of shared responsibility and collective action". When members of the organization have the same perceptions of how to interact with each other, they can avoid possible misunderstandings in their communication and have more opportunities to freely exchange their ideas, resources and information.

\subsection{Social capital and entrepreneurial orientation}

According to researchers, having the strategic resources necessary to translate an entrepreneurial orientation into better performance is crucial (Hitt et al., 2001). As a matter of fact, the set of social interactions can provide the information, resources and support needed by entrepreneurs (Puhakka, 2006) and therefore social capital can be viewed as a strategic resource. Better yet, social capital is a considered as a strategic resource because it is unique, difficult to imitate and invisible to competitors (Galaskiewicz and Zaheer, 1999; Stam and Elfring, 2008). According to researchers, a company's membership in a social network provides it with the benefit of obtaining a competitive advantage over its rivals (Tsai and Ghoshal, 1998), the generation of intellectual capital (Nahapiet et Ghoshal, 1998), the attainment of knowledge-based resources and capacities (Rowley, Behrens and Krackhardt, 2000), access to new markets and technologies and finally the development of new capacities in an efficient manner (Anderson et al., 2007; Puhakka, 2006). The resources obtained through the firm's social network allow it to improve its competitiveness and place it in a privileged position to provide more differentiated products and meet customer needs in a timely manner (Sirmon, Hitt, and Ireland, 2007). These advantages can be achieved when the organization is in the center of a dense network. Dense networks allow 
International Journal of Social Science and Economic Research

ISSN: 2455-8834

Volume:06, Issue:04 "April 2021"

more opportunities to be identified and can promote faster flows of tacit-type information. Despite the advantages of such network, some authors establish the predominance of its negative effects (Granovetter, 1992; McEvily and Zaheer, 1999; Hansen, 1999; Inkpen and Tsang, 2005; Obstfeld, 2005). Inother words, individuals who find themselves in the middle of dense networks with higher strength in their bonds may benefit from faster transmission of information but face a redundancy problem where information and knowledge are already transmitted and a problem of lack of innovation emerges (Koka and Prescott, 2002). As a result, the company faces a lack of detection of new opportunities and an eventual reduction in proactivity and innovation.

Thus, the negative effects of the structural dimension of social capital outweigh the positive effects on entrepreneurial orientation. Specifically, the company's location in networks with greater density and strength in their links will have a negative influence on entrepreneurial orientation. Following that, we propose the following hypothesis:

\section{H1a. The structural dimension of social capital has a negative effect on entrepreneurial orientation}

According to Kaasa (2009), relationships characterized by strong trust avoid monitoring costs and devote more time and money to the development of innovative activities. Consequently, relational social capital enables the company to increase its innovation, learning and creativity (Meeus, Oerlemans and Hage, 2001). According to Larson (1992), some actors are susceptible to opportunistic behavior when transmitting new information, but other actors exchange valuable information easily and without constraints thanks to the trust that characterizes their relationship. Trust is an essential factor allowing some actors, but not others, to access new information and to perceive entrepreneurial opportunities (Kwon and Arenius, 2010). Thus, greater trust between actors, allows the exchange of confidential information, reduces the need to monitor other actors, reduces opportunistic behavior and increases the chances of developing mutual collaborative actions. Consequently, greater relational social capital improves the entrepreneurial orientation of companies by perceiving new opportunities, the probability of developing new innovations or taking risky actions before their competitors. In this sense, we propose this:

\section{H1b. The relational dimension of social capital has a positive effect on entrepreneurial orientation}

Parra-Requena et al. (2010) suggest that cognitive social capital is essential for the acquisitionof external knowledge. As a matter of fact, when individuals share the same codes and languages, they perceive information in the same way and they tend to interact similarly and therefore, they can avoid any potential misunderstanding in communications (Tsai and Ghoshal, 1998). According to researchers, the higher the cognitive dimension of social capital, the more actors 
International Journal of Social Science and Economic Research

ISSN: 2455-8834

Volume:06, Issue:04 "April 2021"

can take advantage of external resources and information, which promotes risk-taking (Iturrioz, Aragon and Narvaiza, 2015). According to Gnyawali and Madhavan (2001), cognitive social capital facilitates the understanding of the behavior and practices of competitors and the correct interpretation of their actions. To conclude, when different social actors share the same norms, cultures and goals, they avoid misunderstandings since they are better placed to understand external knowledge and information. They proactively seize opportunities by opting for the creation of new, creative products and services and they are more inclined to take risky actions.

Thus, we propose the following hypothesis:

\section{H1c. The cognitive dimension of social capital has a positive effect on entrepreneurial orientation}

\subsection{The role of organizational learning}

\subsubsection{Social capital and organizational learning}

The resources provided by actors external to the firm are essential for organizational learning. In fact, all the information that comes from outside the organization is a trigger for organizational improvement (Garvin, 1993). According to researchers, organizational learning is a continuous process of acquiring and interpreting information leading to the creation of new knowledge (Brown and Duguid, 1998; Davis and Botkin, 1994; Galunic and Rodan, 1998; Huber, 1991). Entrepreneurial firms must provide an environment conducive to learning. Organizational learning is a kind of correction or adjustment of the organization's behavior to changes in its environment through trial and error (Leroy, 2013). Learning is thus understood both as adaptation and as a process of error detection and correction (Leroy, 2013). It is a process by which the company learns new market information and knowledge, know-how, new technologies and new practices (Argyris and Schon, 1996, Nonaka andTakeuchi, 1995).

According to March (1991), organizational learning is made up of two dimensions: exploitation and exploration. Exploration is defined as "the pursuit of knowledge and of things that might be known" (Levinthal and March, 1993). Exploration is the ability to adopt unique new processes, products and services (Yalcinkaya et al., 2007). Exploration is synonymous with experimentation, discovery, research and prospecting with the intention of creating new knowledge. Operation is defined as "the refinement and extension of existing skills, technologies and paradigms with positive, immediate and predictable returns". Exploitation is also "The use and development of things already known" (Levinthal and March, 1993). According to other researchers, exploitative learning can be defined as the ability to continually improve one's existing resources and processes (Yalcinkaya et al., 2007). Additionally, exploitation refers to 


\section{International Journal of Social Science and Economic Research}

ISSN: $2455-8834$

Volume:06, Issue:04 "April 2021"

learning from knowledge and skills that are familiarwith current business experiences. This type of learning is characterized by refinement, choice, production, efficiency, selection, implementation and execution. According to researchers, organizational prosperity happens when a company manages to strike a balance between exploiting its current skills and exploring future ones (Simsek, 2009; Raisch, S., Birkinshaw, J., Probst, G., \& Tushman, 2009, Wang and Rafiq, 2012), this is phenomenon is known as ambidexterity. Previous studies on ambidexterity and research on entrepreneurship (De Carolis and Saparito, 2006; Liao and Welsch, 2005, for example) have emphasized the role of inter-organizational networks in the realization of ambidexterity (Hoang and Rothaermel, 2010; Tsai, 2001; De Carolis and Saparito, 2006; Liao and Welsch, 2005).

External social capital helps companies continue to explore or operate by providing access to new ideas and complementary knowledge outside the confines of a company (Taylor \& Helfat, 2009; Inkpen \& Tsang, 2005). Structural social capital exerts an influence on the capture, transformation and accumulation of knowledge (Bao et al., 2012). Relationships facilitate access to potentially useful knowledge, ideas or resources and increase the likelihood of organizational knowledge transfer (Reagans \& McEvily, 2003). When exchange partners increase the frequency of their interactions, they feel more comfortable and their mutual trust increases which will strengthen the skills and problem-solving abilities of members of the organization and encourage them to seek new knowledge (Campopiano et al., 2016).

In a context of risk, uncertainty and high complexity, a social network in which members share strong affinities positively influences the transfer of knowledge and the performance of the company in general. Indeed, this influence manifests itself following the creation of common norms and values between the members, also the confidence which indicates the conviction of a company that the other actors of the network will not act in an opportunistic manner (Nahapiet and Ghoshal, 1998; Tsai and Ghoshal, 1998).

Trust increases the interactions and proximity between the actors in a relationship, thus improving their ability to recognize and effectively assess existing information (Adler and Kwon 2002). Tsai and Ghoshal (1998) found that trust contributed to the efficient exchange and recombination of resources.

According to researchers, shared vision and systems are important cognitive elements that characterize social relationships between individuals and influence knowledge transfer (Inkpen and Tsang, 2005). Moreover, the shared vision and systems promote mutual understanding and constitute an essential linkage mechanism that helps the different actors to integrate knowledge and therefore facilitate organizational learning. 
Following that, we propose the following hypothesis:

\section{H2a: structural social capital has a positive effect on organizational learning \\ H2b: relational social capital has a positive effect on organizational learning}

\section{H2c: cognitive social capital has a positive effect on organizational learning}

\subsubsection{Organizational learning and entrepreneurial orientation}

Firms evolve in the center of a dynamic environment that is to say in constant change and evolution (Lumpkin and Dess, 1996), so they must always remain synchronized with the changing environment, to renew their ways of productivity, to act and respond quickly to changes and customer needs and to seize all the opportunities offered in the market before competitors.

It is a fact that having the ability to learn from past mistakes, wrong decisions, failures or other sources such as social capital or human capital, is a way to succeed and achieve better results.

Garvin (1993) suggests that "a learning organization is an organization competent at creating, acquiring and transferring knowledge and modifying its behavior to reflect new knowledge and perspectives".

Firms that have an entrepreneurial orientation are more likely to focus their attention and efforts on maximizing and identifying new opportunities (Wiklund and Shepherd, 2003). When firms increase their entrepreneurial tendencies, it is likely that concerns and engagement in learning will increase rapidly in order to collect relevant information on opportunities (Rhee et al., 2010). Wang (2008) asserts that "Entrepreneurial orientation creates a fertile internal environment for organizational learning. The more entrepreneurial a company is, the more it is oriented towards learning, the more it inculcates values that promote commitment to learning, openness and a shared vision". The learning orientation was conceptualized as internal company values (commitment to learn, openness and shared vision) that influence the propensity of employees to create and use the knowledge acquired.

Such evidence suggests that companies with a high level of entrepreneurial orientation actively seek out new knowledge. They are best placed to acquire and incorporate this knowledge. Based on these arguments, we propose the following hypothesis:

\section{H3. Organizational learning has a positive effect on entrepreneurial orientation}




\subsubsection{The mediating role of organizational learning}

Commitment to learning positively influences the relationship between entrepreneurial orientation and performance (Wang, 2008), More proactive, risk tolerant and innovative companies have a culture of information sharing and learning, which enables opportunities to be exploited more quickly than their rivals (Fosfuri and Tribó, 2008; Slater and Narver, 1995). Therefore, companies can only be able to develop a higher entrepreneurial orientation unless they are able to transform the resources obtained through their social capital in order to harness and explore new knowledge and opportunities. Thus, regardless of the direct effect of social capital, if companies direct their social capital towards the development of its organizational learning, it improves its entrepreneurial orientation.

Following that, we propose the following hypothesis:

\section{H4. Organizational learning plays a mediating role in the relationship between socialcapital (structural, cognitive and relational) and entrepreneurial orientation.}

In sum, we expect that the effect of SC on EO is mediated by a OL. We visualize these relationships in the research model below (Figure 1).

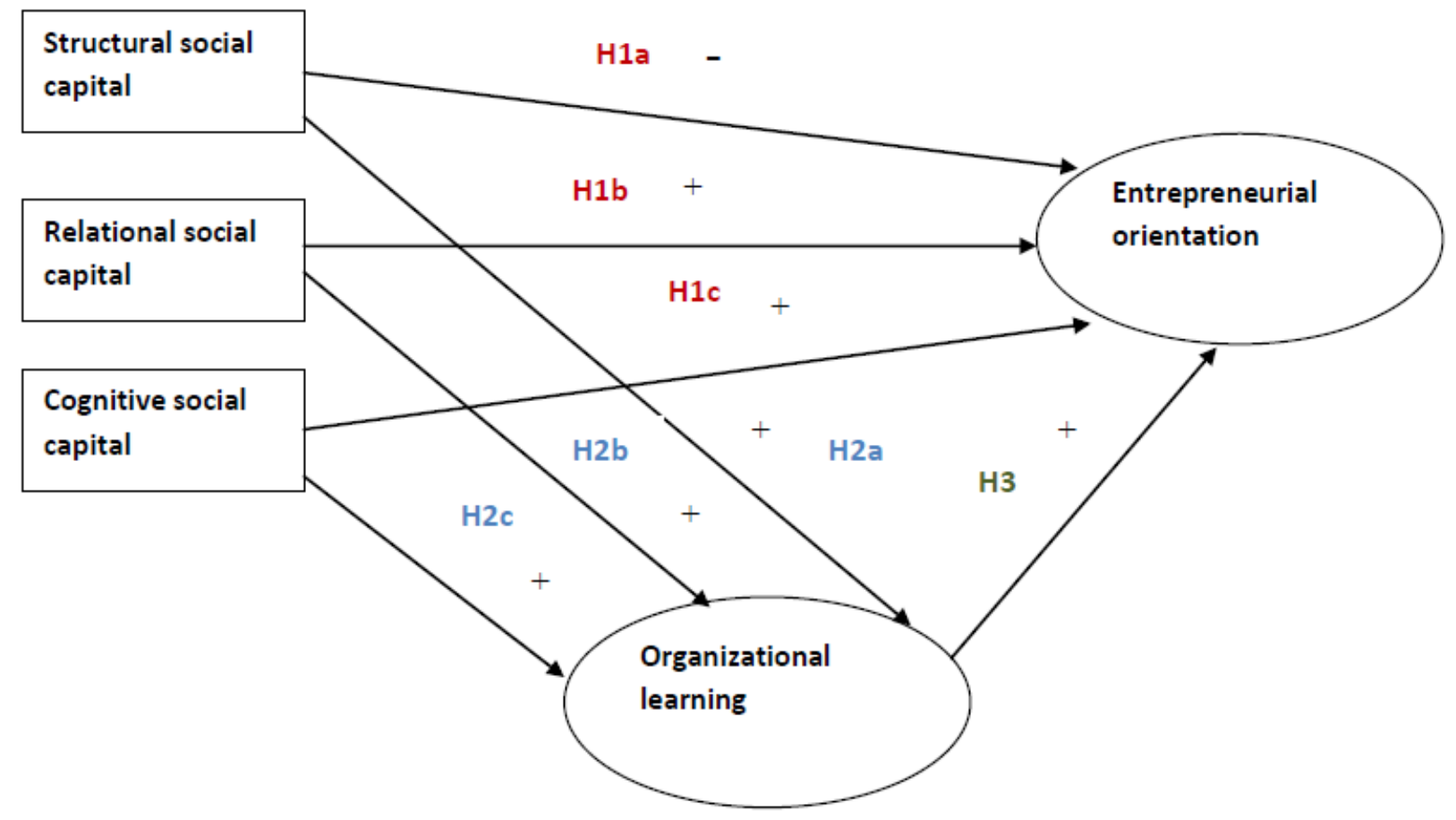

Figure 1: The research model 


\section{Methodology}

\subsection{Sample}

The field setting of this research consists of a convenience sample composed of 235 companies located throughout Tunisia. These companies are of different sizes, operating in various industries and of different ages. The reason why this research focuses on specifically this variety of companies is because the propensity to adopt an entrepreneurial orientation and the fact that having social capital is observable in young companies as well as older ones, and in small companies as well as in large ones. (Barett and Weinstein, 1998). Also, the reason behind choosing to work on several activity sectors is to provide generalizable and closer to reality results. The survey targeted senior executives working within the companies because they are the most affected by the company's strategic choices. According to Zahra (1996) and Yusuf (2002), senior managers are the best informed about firm's entrepreneurial efforts. After checking returned surveys, 33 questionnaires were rejected for incompleteness, leaving 202 questionnaires usable for further data analysis.Table 1 summarizes the descriptive statistics.

Before distributing the questionnaires, a pre-test with 15 senior managers (according toEvrard et al 2003, the number of people questioned during a pre-test should be between 12 and 30 people) was carried to check the clarity of the questions and gather feedback from respondents in terms of comments and suggestions. During this phase, no ambiguity was detected and the majority of respondents did not experience difficulty in answering the questions and they said that the questionnaire is generally understandable.

Table 1 : Profile of respondents

\begin{tabular}{|c|c|c|}
\hline \multicolumn{2}{|c|}{ Respondent caracteristics } & $\begin{array}{c}\text { Pourcenta } \\
\text { ge }\end{array}$ \\
\hline \multirow{3}{*}{ Gender } & Female & $27.7 \%$ \\
& Male & $72.3 \%$ \\
\hline Age & $20-30$ & $14.9 \%$ \\
& $30-40$ & $31.9 \%$ \\
$40-50$ & $31.9 \%$ \\
& 50 and more & \\
\hline & Organizational caracteristics \\
\hline Sector of activity & Service & $66.34 \%$ \\
\hline
\end{tabular}


International Journal of Social Science and Economic Research

ISSN: 2455-8834

Volume:06, Issue:04 "April 2021"

\begin{tabular}{|c|c|c|}
\hline \multirow{2}{*}{ Size } & $\begin{array}{c}\text { Very small / small } \\
\text { business } \\
\text { Medium enterprise } \\
\text { Big business }\end{array}$ & $\begin{array}{c}1 \% \\
95 \% \\
\end{array}$ \\
\hline Firm & $\begin{array}{l}\text { Less than five } \\
\text { age } \\
\text { years More than } \\
\text { five years }\end{array}$ & $\begin{array}{c}11.9 \% \\
88.1 \%\end{array}$ \\
\hline
\end{tabular}

\subsection{Measures}

The scales used to measure the constructs were obtained from previous literature. All items were measured on seven-point Likert scales, ranging from "1" (strongly disagree) to "7" (strongly agree), except for the Organizational Learning scale in which we used two dimensions measured on five items.

\subsubsection{The dependent variable: entrepreneurial orientation}

Proactivity was measured by questioning managers on their propensity to lead rather than to follow in terms of the development of new procedures, technologies, new products or services (Miller and Friesen, 1978; Covin and Slevin, 1989; Wang and Altinay, 2012). 6 items were used to measure this dimension. A 7-point measurement scale was adopted ranging from 1: strongly disagree to 7 : strongly agree

Risk-taking was measured by asking executives about their tendency to engage in risky projects and on their propensity to take bold rather than prudent acts in order to achieve their goals (Lumpkin and Dess, 1996; Wang and Altinay, 2012). 3 items were used to measure this dimension. A 7-point measurement scale was adopted ranging from 1: strongly disagree to 7: strongly agree

Innovativeness: The measure of innovativeness was made by adopting two items from Miller and Friesen (1983) and one item from Hurt et al. (1977) because according to Lumpkin and Dess (1996), Miller's (1983) measures could not assess the general propensity of a firm to adopt innovative behavior but rather focused exclusively on the product-market and aspects technological innovation (Wang and Altinay, 2012). 3 items were used to measure the innovativeness of the company. A 7-point measurement scale was adopted ranging from 1: strongly disagree to 7 : strongly agree

\subsubsection{The independent variable: social capital}


International Journal of Social Science and Economic Research

ISSN: 2455-8834

Volume:06, Issue:04 "April 2021"

The structural dimension: the scale proposed by Maula, Autio and Murray (2003) was used to measure the links and the configuration of the network. This scale allows the measurement of proximity and strength of relationships and network configuration. The scale used was adapted from Molina and Ares (2007), and has been used in studies such as those by Parra- Requena, Ruiz-Ortega and Garcia-Villaverde (2012) (Rodrigo-Alarcon, García-Villaverde, Ruiz -Ortega, Parra-Requena, 2018). 6 items were used to measure this dimension by adopting a 7-point measurement scale ranging from 1: strongly disagree to 7 : strongly agree.

The relational dimension: to measure the relational dimension, the scale proposed by Kale etal. (2000) was used to measure trust (Rodrigo-Alarcon, García-Villaverde, Ruiz-Ortega, ParraRequena, 2018). 5 items were used to measure the relational dimension by adopting a 7-point measurement scale ranging from 1: strongly disagree to 7: strongly agree.

The cognitive dimension: the cognitive dimension was measured according to the objectives and the shared culture. We adopted the scales used by Tsai and Ghoshal (1998) and Yli- Renko et al (2001) to measure shared objectives and the scale proposed by Simonin (1999) to measure the culture shared between network actors (Rodrigo- Alarcon, García-Villaverde, Ruiz-Ortega, Parra-Requena, 2018). 8 items were used to measure the cognitive dimension by adopting a 7point measurement scale ranging from 1: strongly disagree to 7 : strongly agree

\subsubsection{The mediating variable}

Organizational learning is made up of 2 dimensions: Exploitation and exploration. To measure exploratory learning and exploitation we used scales adopted by several researchers such as Atuahene-Gima (2005), He and Wong (2004), Katila and Ahuja (2002), Yalcinkaya, Calantone and Griffith (2007) and Li, Chen, Liu and Peng (2012). The two dimensions are measured by five items each ranging from 1: strongly disagree to 5: strongly agree

\subsection{Analysis}

To develop the empirical analysis of this research, we used structural equation analysis. In this sense, we used Partial Least Squares (PLS) with SmartPLS software. This technique is suitable for data analysis during the early stages of theory development when the theoretical model is not definitively determined. The minimum PLS requirements for the sample, the measurement scale and the distribution of observable variables lead to the conclusion that this is the most appropriate analysis technique for this study. Plus, it doesn't need data normality. (Falk \& Miller, 1992)

The evaluation of the research model using the partial least squares (PLS) method follows a two- 
International Journal of Social Science and Economic Research

ISSN: 2455-8834

Volume:06, Issue:04 "April 2021"

step process (Chin, 2010). The first step is to evaluate the measurement model byexamining the reliability, the convergent validity and discriminant validity (Schutt, 2015). Then, the second step consists in evaluating the structural model by testing the significance of the coefficients between the constructs of the model.

\subsection{Results}

\section{Measurement model evaluation}

The reliability test ensures that the measurements are error-free and therefore gives consistent results (Fornell and Larcker, 1981). The measuring instrument has good reliability if the Cronbach's alpha coefficient and composite reliability (CR) is equal to or greater than 0.7 (Fornell and Larcker, 1981; Urbach and Ahlemann, 2010). All Cronbach and CR alpha scores exceed the recommended value of 0.70 (Nunnally and Bernstein, 1994), indicating that all constructs have good reliability.

Convergent and discriminant validity: To assess the convergent validity, we used the Average Variance Extracted (AVE). All constructs exceeded the recommended threshold of 0.5 (Fornell and Larcker, 1981). To determine the discriminant validity of constructs, thesquare root of the AVE of each variable must be greater than its correlations with any otherconstruct (Fornell and Larcker, 1981). As shown in Table 2, the bold diagonal values represent the square root of the AVEs, which are greater than the correlation of any variable with each other. This clearly indicates the distinct character of each of these constructions.

Table 2. The validity of the construct

\begin{tabular}{|l|l|l|l|l|}
\hline & Cronbach's Alpha & rho_A & $\begin{array}{l}\text { Composite } \\
\text { Reliability(CR) }\end{array}$ & $\begin{array}{l}\text { Average } \\
\text { Variance } \\
\text { Extracted } \\
\text { (AVE) }\end{array}$ \\
\hline $\begin{array}{l}\text { Organizational } \\
\text { learning }\end{array}$ & 0,946 & 0,949 & 0,954 & 0,677 \\
\hline Cognitive dimension & 0,832 & 0,855 & 0,859 & 0,543 \\
\hline Relational dimension & 0,773 & $-0,052$ & 0,759 & 0,635 \\
\hline Structural dimension & 0,758 & 0,379 & 0,805 & 0,817 \\
\hline Innovativeness & 0,838 & 0,870 & 0,882 & 0,562 \\
\hline Risk taking & 0,836 & 0,662 & 0,804 & 0,579 \\
\hline Proactivity & 0,821 & 0,848 & 0,893 & 0,736 \\
\hline
\end{tabular}


International Journal of Social Science and Economic Research

ISSN: 2455-8834

Volume:06, Issue:04 "April 2021"

Table 3. Correlation coefficients and square root of AVEs

\begin{tabular}{|l|l|l|l|l|l|l|l|}
\hline Construct & 1 & 2 & 3 & 4 & 5 & 6 & 7 \\
\hline 1-proactivity & $\mathbf{0 . 8 5 8}$ & & & & & & \\
\hline 2-risk taking & 0.710 & $\mathbf{0 . 7 6 1}$ & & & & & \\
\hline 3-innovativeness & 0.533 & 0.662 & $\mathbf{0 . 7 4 8}$ & & & & \\
\hline $\begin{array}{l}\text { 4-relational } \\
\text { socialcapital }\end{array}$ & 0.285 & 0.349 & 0.365 & $\mathbf{0 . 7 9 7}$ & & & \\
\hline $\begin{array}{l}\text { 5-structural } \\
\text { socialcapital }\end{array}$ & 0.232 & 0.169 & 0.197 & 0.134 & $\mathbf{0 . 9 0 3}$ & & \\
\hline $\begin{array}{l}\text { 6-cognitive } \\
\text { socialcapital }\end{array}$ & 0.404 & 0.457 & 0.360 & 0.210 & 0.004 & $\mathbf{0 . 7 3 4}$ & \\
\hline $\begin{array}{l}\text { 7- } \\
\text { organizational } \\
\text { learning }\end{array}$ & 0.787 & 0.698 & 0.820 & 0.362 & 0.236 & 0.350 & $\mathbf{0 . 8 2 3}$ \\
\hline
\end{tabular}

Note : The numbers in bold are the square root of the AVE of each construct.

\subsection{Evaluation of the structural model}

According to Table 3:

1. The effect of the structural dimension on entrepreneurial orientation is positive $(0.010)$ is not significant $(p>0.05)$

We conclude that the H1a hypothesis is unconfirmed.

2. The effect of the relational dimension on entrepreneurial orientation is negative $(-0.044)$ and not significant $(\mathrm{p}>0.05)$.

We conclude that hypothesis $\mathrm{H} 1 \mathrm{~b}$ is unconfirmed.

3. The effect of the cognitive dimension on entrepreneurial orientation is positive $(0.141)$ and significant $(\mathrm{p}<0.05)$.

We conclude that the H1c hypothesis is confirmed

4. The effect of the structural dimension on organizational learning is positive (0.262) and not significant $(\mathrm{p}>0.05)$.

We conclude that the $\mathrm{H} 2 \mathrm{a}$ hypothesis is unconfirmed.

The effect of the relational dimension on organizational learning is negative $(-0.262)$ and not significant $(\mathrm{p}>0.05)$. 


\section{International Journal of Social Science and Economic Research}

ISSN: $2455-8834$

Volume:06, Issue:04 "April 2021"

We conclude that the $\mathrm{H} 2 \mathrm{~b}$ hypothesis is unconfirmed

The effect of the cognitive dimension on organizational learning is positive (0.337) and significant $(\mathrm{p}<0.05)$.

We conclude that the $\mathrm{H} 2 \mathrm{c}$ hypothesis is confirmed

5. The effect of organizational learning on entrepreneurial orientation is positive $(0.780)$ and significant $(\mathrm{p}<0.05)$.

We conclude that the $\mathrm{H} 3$ hypothesis is confirmed

6. To test the mediating effect of the mediating variable organizational learning, we use the 4 steps proposed by Baron and Kenny (1986). The first step consists in verifying that the link which exists between the independent variable that is social capital (relational, structural and cognitive) and the dependent variable that is entrepreneurial orientation is significant to ensure that there is an impact to be mediated. In our case, only the cognitive dimension exerts a positive (0.141) and significant $(\mathrm{p}=0.00)$ effect on the entrepreneurial orientation, so this step is verified for the cognitive dimension. The second step consists in showing that the independent variable exerts a significant effect on the mediator variable, in our case and according to table 4 only the cognitive dimension exerts a positive (0.337) and significant $(\mathrm{p}=0.00)$ effect on organizational learning. Therefore, this step is verified for the cognitive dimension of social capital. The third step consists in showing that the link between the mediating variable and the dependent variable is significant. In Table 4, we note that this step is verified because the effect is positive (0.780) and significant $(\mathrm{p}=0.00)$. Finally, to establish the existence of a complete mediation by the mediating variable, the relation coefficient linking the dependent variable and the independent variable must be zero, it is a matter of verifying that this coefficient is equal to 0 in the presence of the mediating variable, otherwisethe mediation is partial. In our case and according to Table 5, when we introduce themediating variable, we notice that the effect of the relational dimension on entrepreneurial orientation decreases (-0.204 and not significant) and the effect of the cognitive dimension increases ( 0.263 and significant) and the effect of the structural dimension on entrepreneurial orientation also increases (0.204 and significant). This last step is not verified for the cognitive dimension. According to Baron and Kenny (1986) if only the first 3 stages are verified then the mediating role is partial. Based on these results, we can partially confirm Hypothesis 4. 
International Journal of Social Science and Economic Research

ISSN: 2455-8834

Volume:06, Issue:04 "April 2021"

Table 4 : the direct effects

\begin{tabular}{|c|c|c|c|c|c|}
\hline & Coefficient & $\begin{array}{l}\text { Sample } \\
\text { Mean(M) }\end{array}$ & $\begin{array}{l}\text { Standard } \\
\text { Deviatio } \\
\mathrm{n}\end{array}$ & $\begin{array}{l}\mathrm{T} \\
\text { Statistics }\end{array}$ & $\begin{array}{l}\mathrm{P} \\
\text { Values }\end{array}$ \\
\hline $\begin{array}{l}\text { Organizational Learning - } \\
>\quad \text { Entrepreneurial } \\
\text { Orientation }\end{array}$ & 0,780 & 0,784 & 0,038 & 20,473 & 0,000 \\
\hline $\begin{array}{l}\text { Cognitive Dimension - } \\
>\text { Organizational Learning }\end{array}$ & 0,337 & 0,358 & 0,076 & 4,441 & 0,000 \\
\hline $\begin{array}{ll}\text { Cognitive } & \text { dimension - } \\
> & \text { Entrepreneurial } \\
\text { orientation } & \end{array}$ & 0,141 & 0,130 & 0,039 & 3,612 & 0,000 \\
\hline $\begin{array}{l}\text { Relational Dimension - } \\
>\text { Organizational Learning }\end{array}$ & $-0,262$ & $-0,019$ & 0,259 & 1,011 & 0,313 \\
\hline $\begin{array}{ll}\text { Relational } & \text { Dimension - } \\
> & \text { Entrepreneurial } \\
\text { orientation } & \end{array}$ & $-0,044$ & 0,006 & 0,060 & 0,737 & 0,461 \\
\hline $\begin{array}{l}\text { Structural Dimension - } \\
>\text { Organizational Learning }\end{array}$ & 0,262 & 0,066 & 0,272 & 0,962 & 0,336 \\
\hline $\begin{array}{l}\text { Structural Dimension } \quad-> \\
\text { Entrepreneurial orientation }\end{array}$ & 0,010 & 0,025 & 0,047 & 0,211 & 0,833 \\
\hline
\end{tabular}

Table 5 : the indirect effects

\begin{tabular}{|c|c|c|c|c|c|}
\hline & Coefficient & $\begin{array}{l}\text { Sampl } \\
\text { eMean } \\
\text { (M) }\end{array}$ & $\begin{array}{l}\text { Standard } \\
\text { Deviatio } \\
\mathrm{n} \\
(\text { STDEV) }\end{array}$ & $\begin{array}{l}\text { T } \\
\text { Statistics }\end{array}$ & $\begin{array}{l}\mathrm{P} \\
\text { Values }\end{array}$ \\
\hline $\begin{array}{lrr}\text { Cognitive } & \text { Dimension } & -> \\
\text { Organizational } & \\
\text { Learning } & & \\
\text { Orientation } & & \text { Entrepreneurial }\end{array}$ & 0,263 & 0,272 & 0,060 & 4,343 & 0,000 \\
\hline $\begin{array}{l}\text { Relational } \\
\text { Organizational } \\
\text { Learning } \\
\text { Orientation }\end{array}$ & $-0,204$ & $-0,009$ & 0,203 & 1,003 & 0,316 \\
\hline $\begin{array}{lrr}\text { Structural } & \text { Dimension } \\
\begin{array}{l}\text { Organizational } \\
\text { Learning } \\
\text { Orientation }\end{array} & & \\
\end{array}$ & 0,204 & 0,052 & 0,210 & 0,970 & 0,333 \\
\hline
\end{tabular}




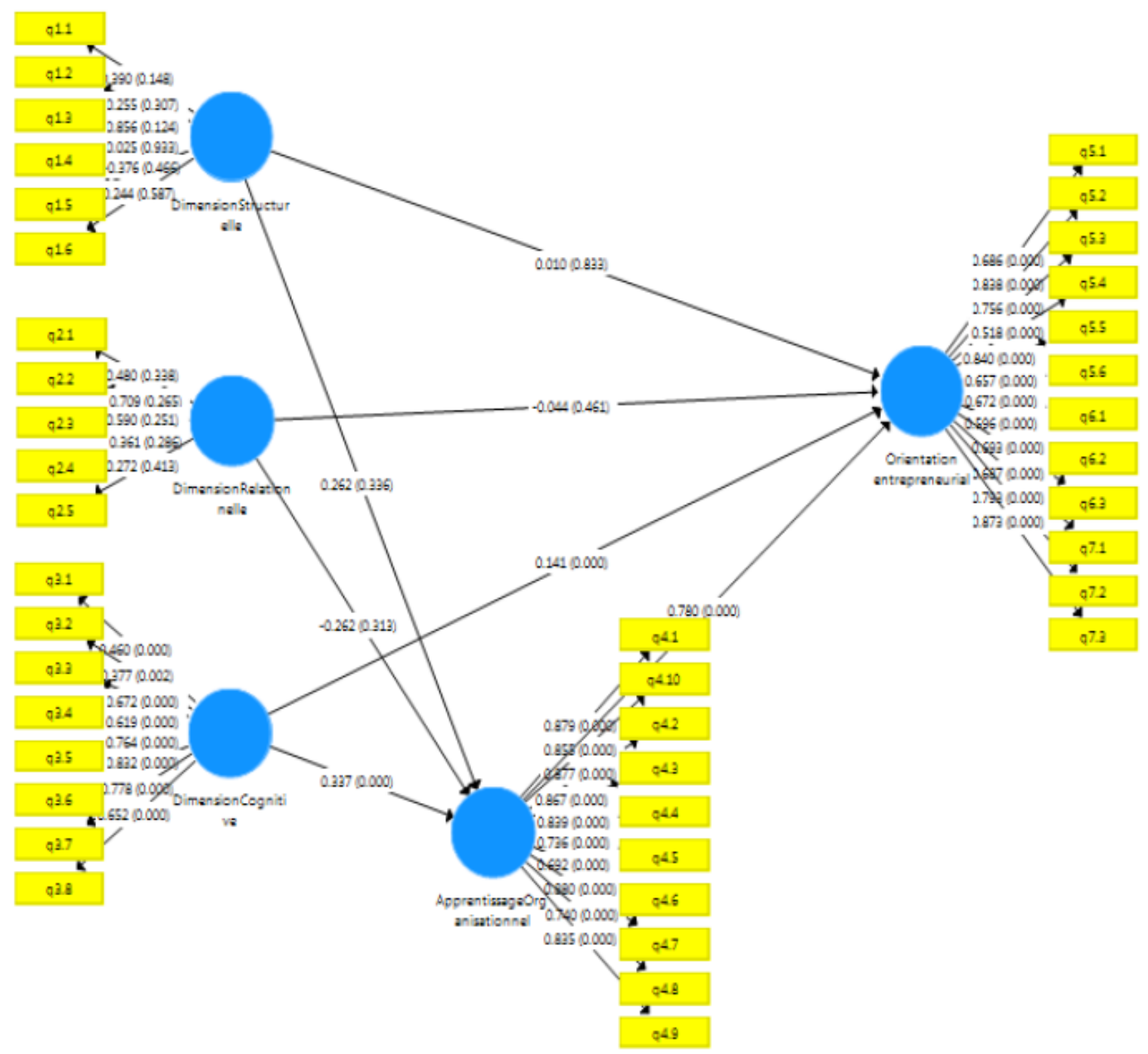

Figure 2. The structural model with SmartPLS software

\section{Discussion and conclusions}

This study responds to the call for a deeper investigation of the antecedents of entrepreneurial orientation (Covin \& Lumpkin, 2011). This research clarifies the divergent effect of each dimension of social capital on entrepreneurial orientation through organizational learning. The results obtained show that only the cognitive dimension has a positive and significant effecton entrepreneurial orientation and that the mediating effect of learning in this relationship is only partial. Thus, when members of an organization have the same visions, culture, goals and perceptions, they can avoid possible misunderstandings in their communication and have 


\section{International Journal of Social Science and Economic Research}

ISSN: $2455-8834$

Volume:06, Issue:04 "April 2021"

more opportunities to freely exchange ideas, resources and information, so they proactively seize opportunities by opting for the creation of new creative products and services and they are more inclined to take risks. This result confirms the results obtained by Rodrigo-Alarconet al (2018) who found that the cognitive dimension has a positive effect on entrepreneurial orientation. The relational dimension does not have a positive effect on the entrepreneurial orientation, that is to say that the trust and the nature of the social relations that exist between the actors do not contribute to the development of the entrepreneurial orientation, these results differ to those of Rodrigo-Alarcon et al (2018) who found that the relational dimension of social capital has a positive effect on entrepreneurial orientation. The structural dimension does not have a negative effect on entrepreneurial orientation, unlike the results found by Rodrigo-Alarcon et al (2018) which show that the structural dimension has a slightly negative effect.

The results obtained show that the structural and relational dimension do not have a significant effect on organizational learning, only the cognitive dimension has a positive and significant effect on organizational learning, which means that shared systems of meanings and language facilitate the exchange of information, learning and the creation of knowledge that allows individuals to share their thought processes. These common ways of looking at the world help people understand and grasp new information and knowledge (Grant, 1996; Nonaka, 1994). Firms with high levels of cognitive social capital can achieve a good understanding of valuable information and, if they act proactively, are able to better use the knowledge to identify new opportunities (Tsang, 2010). So cognitive social capital plays a particularly important role in the development of organizational learning. Thus, we observe the importance of sharing goals, culture and values with the actors with whom companies interact to achieve organizational learning.

Finally, we clarified the role of organizational learning in relating social capital to entrepreneurial orientation. According to our results, organizational learning partially mediates the relationship between cognitive social capital and entrepreneurial orientation because we notice a positive and significant direct effect and also a positive and significant indirect effect, this mediation would have been total if only the indirect effect was significant and the direct effect was insignificant, and in case the indirect effect was insignificant then there would be no mediation. At the level of the relational and structural dimension, the direct and indirect effect are both insignificant, that is, there is no mediation at the level of these twodimensions.

\section{Managerial implications}

The results of our study suggest several implications for Tunisian business leaders. Maintaining an orientation focused on organizational learning and the development of social capital should be 


\section{International Journal of Social Science and Economic Research}

ISSN: $2455-8834$

Volume:06, Issue:04 "April 2021"

the mail goal of Tunisian firm leaders if they plan to improve their entrepreneurial orientation.

First, managers must increase the frequency of their contacts with the various social actors such as customers, suppliers, competitors, etc. by organizing regular social events, for example, in which we discuss past performances and experiences. Also, managers can adopt collaborative technologies such as discussion forums and video conferences.

Second, managers can shape networks in contexts favorable to the firm's future actions (Coleman, 1990; Galaskiewicz and Zaheer, 1999; Leonidou et al., 1998; Ritter and Gemünden, 2003). For example, by forging alliances that provides access to knowledge, key technologies or other resources necessary for exploitation and exploration.

Finally, in order to ensure long-term development, companies must maintain a learning orientation. Human resources professionals could devise a motivational mechanism that motivates companies to exploit their exploitation and exploration potential. Indeed, the learning environment will strengthen the willingness of employees to stay involved in the organization. In fact, it is better to focus on investing in employees by offering them the benefit of learning opportunities in order to cultivate their talents.

\section{Theoretical implications}

Investigating the antecedents of entrepreneurial orientation requires further research and exploration, researchers say (Wales, 2016). With this study, and in accordance to Burt (2000), we have studied in a theoretical and empirical way how each dimension of social capital contributes to the generation and development of organizational learning that promotes the development of the entrepreneurial orientation. In accordance with the requests of Wales et al. (2013), this study contributes to the literature by providing a detailed analysis of the antecedents of entrepreneurial orientation, linking three theoretical approaches, namely social capital, entrepreneurial orientation and organizational learning. This study analyzes in depth the heterogeneous effects of each dimension of social capital on entrepreneurial orientation through organizational learning. The results obtained partially confirm those of the study carried out by Rodrigo-Alarcon J., García-Villaverde PM, Ruiz-Ortega MJ and Parra-Requena G., (2018) who studied the effect of social capital on Entrepreneurial orientation through dynamic capabilities. On the other hand, our results made it possible to conclude that only the cognitive dimension of social capital improves the entrepreneurial orientation of companies through a partial mediation of organizational learning and that the structural and relational dimensions have no effect on entrepreneurial orientation. , neither direct effect, nor through organizational learning. 
International Journal of Social Science and Economic Research

ISSN: 2455-8834

Volume:06, Issue:04 "April 2021"

\section{Limitations}

Despite the precautions taken in preparing this research, some limitations should be noted such as the fact that the questionnaire was administered to a single respondent in each company. Responses from more people within the companies would have given wider views and could have clarified more the picture of the situation and the behavior of the company. Therefore, it cannot be claimed that the current study is representative as it could not be generalized. We also understand that, despite the efforts and the measures taken to develop and validate scales, potential bias could have occurred.

\section{Suggestions for future research}

Further research could contribute to the literature of this field in several possible ways. Recommendations include: Firstly, including various categories of employees in the interviews for each company, therefore interviews would not be restrictive to senior managers. Secondly, analyzing the effects of internal firm conditions as antecedents of entrepreneurial orientation such as leadership style, structure, firm culture, and team characteristics. Thirdly, adding two additional dimensions of entrepreneurial orientation, competitive aggressiveness and autonomy, as proposed by Lumpkin and Dess (1996). Finally, it might be beneficial to analyze each dimension of entrepreneurial orientation and organizational learning and their individual effects.

\section{Bibliography}

Adler P. S., et Kwon S.W. (2002), « Social Capital: Prospects for a New Concept», Academy of Management Review, vol.27, $\mathrm{N}^{\circ}$, pp.17-40.

Anderson A.R., Park J. et Jack S.L. (2007), « Entrepreneurial social capital: conceptualizing social capital in new high-tech firms», International Small Business Journal, Vol. 25 No. 3, pp. $243-67$.

Argyris C., et Schon D.A, (1996), « Organizational Learning: A Theory of Action Perspective».

Bao Y., Chen X., et Zhou K. Z. (2012), « External learning, market dynamics, and radical innovation: Evidence from China's high-tech firms», Journal of Business Research, vol.65, N 8 , pp.1226-1233.

Barrett H., et Weinstein A. (1998), « The Effect of Market Orientation and Organizational Flexibility on Corporate Entrepreneurship», Entrepreneurship Theory and Practice, vol.23, $\mathrm{N}^{\circ} 1$, pp.57-70. 
International Journal of Social Science and Economic Research

ISSN: 2455-8834

Volume:06, Issue:04 "April 2021"

Barringer B.R. et Bluedorn A.C. (1999), « The relationship between corporate entrepreneurship and strategic management », Strategic Management Journal, vol.20, pp.421-444.

Bourdieu P. (1986), « The Forms of Capital», Handbook of theory and research for the sociology of education. Westport, CT: Greenwood: 241-54.

Brown J. S., et Duguid P. (1998), « Organizing Knowledge», California Management Review, vol.40, $\mathrm{N}^{\circ} 3$, pp.90-111.

Burt R.S. (1992), « Structural Holes: The Social Structure of Competition», Acta Sociologica, Vol. 37, $\mathrm{N}^{\circ} 4$, pp.426-428.

Campopiano G., Minola T., et Sainaghi R. (2016), « Students climbing the entrepreneurial ladder», International Journal of Contemporary Hospitality Management, vol.28, N6, pp.11151136.

Chin W.W., (2010), «How to Write Up and Report PLS Analyses».

Covin J. G., et Slevin D. P. (1989), « Strategic management of small firms in hostile and benign environments», Strategic Management Journal, vol.10, $\mathrm{N}^{\circ} 1$, pp.75-87.

Davis S. et Botkin J. (1994), « The Coming of Knowledge-Based Business», Harvard Business Review, pp.165-170.

De Carolis D. M., et Saparito P. (2006), « Social Capital, Cognition, and Entrepreneurial Opportunities: A Theoretical Framework», Entrepreneurship Theory and Practice, vol.30, N 1 , pp.41-56.

De Clercq D., Dimov D. et Thongpapanl N.T (2013), « organizational social capital, formalization and internal knowledge sharing in entrepreneurial orientation formation», Entrepreneurship theory and practice, vol.37, pp.505-537.

Dickson P.R. (1992), " Toward a General Theory of Competitive Rationality», Journal of Marketing, Vol. 56, $\mathrm{N}^{\circ} 1$, pp. 69-83.

Evrard Y., Pras B.G., et Roux E., (2003), « Market : Etudes et recherche en Marketing», Dunod, Paris, 3ème édition.

Falk R.F. and Miller N.B. (1992), « A Primer for Soft Modeling», University of Akron Press, Akron. 
International Journal of Social Science and Economic Research

ISSN: 2455-8834

Volume:06, Issue:04 "April 2021"

Fornell C., et Larcker D. F. (1981), « Structural Equation Models with Unobservable Variables and Measurement Error: Algebra and Statistics. », Journal of Marketing Research, vol.18, pp.382-388.

Fosfuri A., et Tribo J. (2008), « Exploring the antecedents of potential absorptive capacity and its impact on innovation performance», Omega, vol.36, N², pp.173-187.

Galunic C. D et Rodan S. (1998). «Resource recombination's in the firm: knowledge structures and the potential for Schumpeterian Innovation. », Strategic Management Journal, Vol 19, pp.1193-1201.

Garvin, D.A. (1993) « Building a Learning Organization», Harvard Business Review, vol.71, pp.78-91.

Gao S., Sung M.C., Zhang J., (2013), « Risk management capability building in SMEs: A social capital perspective», International Small Business Journal, vol.31, N6, pp.677-700.

Gnyawali D. R., et Madhavan R. (2001), «Cooperative Networks and Competitive Dynamics: A Structural Embeddedness Perspective», The Academy of Management Review, vol.26, $N^{\circ} 3$, p.431.

Granovetter M., (1985), « economic action and social structure: the problem of embeddedness»,American journal of sociology, vol.91, N`3, pp.481-510.

Galaskiewicz J. et A. Zaheer (1999), « Networks of competitive advantage», Research in the Sociology of Organizations, pp. 237-261.

Granovetter, M.S. (1992), «Economic Institutions as Social Constructions: A Framework for Analysis», Acta Sociologica, vol.35, N¹,pp.3-11.

Hair, J. F., Ringle, C. M., \& Sarstedt, M. (2013). Partial least squares structural equation modeling: Rigorous applications, better results and higher acceptance. Long Range Planning, 46(1-2), 1-12.

Hansen B.E., (1999), « Threshold elects in non-dynamic panels: Estimation, testing, and inference», Journal of Econometrics, vol.93, pp.345-368.

He Z. et Wong P. (2004), «Exploration and Exploitation: An Empirical Test of the Ambidexterity Hypothesis», Organization Science, vol.15, pp.481-494. 
International Journal of Social Science and Economic Research

ISSN: 2455-8834

Volume:06, Issue:04 "April 2021"

Hitt M.A., Ireland R.D., Camp S.M., et Sexton D.L. (2001), « Guest editors' introduction to the special issue strategic entrepreneurship: Entrepreneurial strategies for wealth creation », Strategic Management Journal, Vol.22, 479-491.

Hoang Ha et Rothaermel F.T., (2010), « Leveraging internal and external experience: exploration, exploitation, and R\&D project performance», Strategic Management Journal, vol.31, pp.734-758.

Huber G. P. (1991), « Organizational Learning: The Contributing Processes and the Literatures», Organization Science, vol.2, $\mathrm{N}^{\circ} 1, \mathrm{pp} .88-115$.

Hurt, H.T.; Joseph, K.; and Cook, C.D. (1977) « Scales for the measurement of innovativeness», Human Communication Research, Vol. 4, No. 1, pp.58-65.

Hsu L.C., et Wang C.H., (2012), « Clarifying the Effect of Intellectual Capital on Performance: The mediating role of dynamic capability», British journal of management, vol.23, $\mathrm{N}^{\circ} 2$.

Ingham M. (1994), «L'apprentissage organisationnel dans les coopérations », Revue Française de Gestion, pp.105-119.

Inkpen A.C., et Tsang E.W.K. (2005), « Social Capital, Networks, and Knowledge Transfer», Academy of Management Review, Vol. 30, Nº1, pp. 146-165.

Ireland R.D., Hitt M.A., et Sirmon D.G. (2003), « A Model of Strategic Entrepreneurship: The Construct and its Dimensions», Journal of Management, vol.29, N6, pp.963-989. 91.

Iturrioz C., Aragón C., et Narvaiza L. (2015), « How to foster shared innovation within SMEs' networks: Social capital and the role of intermediaries», European Management Journal, vol.33, $\mathrm{N}^{\circ}$, pp.104-115.

Katila R. and Ahuja G. (2002), "Something Old, Something New: A Longitudinal Study of Search Behavior and New Product Introduction», Academy of Management Journal, vol.45, pp.1183-1194.

Kaasa A. (2009), « Effects of different dimensions of social capital on innovative activity: Evidence from Europe at the regional level», Technovation, vol.29, №3, pp.218-233.

Koka B. R., et Prescott J. E. (2002), « Strategic alliances as social capital: a multidimensional view», Strategic Management Journal, vol.23, N9, pp.795-816. 
International Journal of Social Science and Economic Research

ISSN: 2455-8834

Volume:06, Issue:04 "April 2021"

Kwon S-W., et Arenius P. (2010), « Nations of entrepreneurs: A social capital perspective»,. Journal of Business Venturing, vol.25, N³, pp.315-330.

Kyrgidou et Spyropoulou (2013), «Drivers and Performance Outcomes of Innovativeness:An Empirical Study", British journal of management, vol.23.

Larson A. (1992), « Network Dyads in Entrepreneurial Settings: A Study of the Governanceof Exchange Relationships», Administrative Science Quarterly, vol. 37, N¹, p.76.

Leana C. R., et Pil F. K. (2006), « Social Capital and Organizational Performance: Evidence from Urban Public Schools», Organization Science, vol.17, N³, pp.353-366.

Leroy F. (2013), « Processus d'apprentissage organisationnel et partages de compétences à l'occasion d'une fusion » thèse présentée par Frédéric Leroy en vue de l'obtention du titre de docteur en sciences de gestion.

Leonidou LC, Katsikeas CS, Piercy NF. Identifying managerial influences on exporting: past research and future directions. Journal of International Marketing 1998; 6(2): 81 - 111.

Liao J., et Welsch H. (2005), « Roles of social capital in venture creation: Key dimensions and research implications», Journal of Small Business Management, vol.43, N4, pp.345-362.

Li Y., Chen H., Liu Y. et Peng M.W. (2012), « Managerial ties, organizational learning, and opportunity capture: A social capital perspective», Asia Pacific Journal of Management, vol.31, $\mathrm{N}^{\circ} 1$

Lumpkin G. T., et Dess G. (1996), « Clarifying the Entrepreneurial Orientation Construct and Linking It to Performance», The Academy of Management Review, vol.21, Nº1, p.135

March J.G. (1991), « Exploration and Exploitation in Organizational Learning», Organization Science, Vol. 2, No.1, pp. 71-87.

McEvily B. et Zaheer A. (1999), « Bridging ties: A source of firm heterogeneity in competetive capabilities », Strategic Management Journal, vol.20, pp.1133-1156.

Meeus M. T. H., Oerlemans L. A. G. et Hage J. (2001), «Patterns of Interactive Learning in a High-tech Region», Organization Studies, vol.22, N¹, pp.145-172.

Miller D., et Friesen P.H. (1978), « Archetypes of strategy formulation », Management Science, vol.24, pp.921-933. 


\section{International Journal of Social Science and Economic Research}

ISSN: $2455-8834$

Volume:06, Issue:04 "April 2021"

Molina, F. X., et Ares, M. A. (2007). « Facteurs inhibiteurs de la délocalisation des activités dans les districts industriels. », Le cas de la céramique de Castell on. Cuadernos de Estudios Empresariales, vol. 17, pp. 9-30

Miller D. (1983), « The correlates of entrepreneurship in three types of firms», Management Science, Vol .29, pp .770-791.

Miller D., et Friesen P.H. (1978), « Archetypes of strategy formulation », Management Science, vol.24, pp.921-933.

Mintzberg H. (1973), « Strategy-Making in Three Modes», California Management Review, vol.16, $\mathrm{N}^{\circ} 2$, pp.44-53.

Nahapiet J., et Ghoshal S. (1998), « Social Capital, Intellectual Capital, and the Organizational Advantage», The Academy of Management Review, vol.23, N², p.242.

Naman J. L., et Slevin D. P. (1993), « Entrepreneurship and the concept of fit: A model and empirical tests», Strategic Management Journal, vol.14n N², pp.137-153.

Nonaka I., et Tkeuchi H. (1995), « The Knowledge-Creating Company: How Japanese companies Create the Dynamics of Innovation», Oxford University Press.

Nunnally J.C. et Bernstein I.H. (1994), « The Assessment of Reliability. », Psychometric Theory, vol.3, pp.248-292

Obstfeld D. (2005), "Social Networks, the Tertius Iungens Orientation, and Involvement in Innovation », Administrative Science Quarterly, Vol.50, No.1, pp. 100-130.

Parra-Requena, G., Ruiz-Ortega, M. J., et Garcia-Villaverde, P. M. (2012). " Towards pioneering through capabilities in dense and cohesive social networks. », Journal of Business \& Industrial Marketing, vol.27, pp. 41-56.

Parra-Requena G., Molina-Morales F.X., et Garcia-Villaverde P. M. (2010), « The Mediating Effect of Cognitive Social Capital on Knowledge Acquisition in Clustered Firms», Growth and Change Vol. 41 No. 1, pp. 59-84.

Puhakka V. (2006), «Effects of social capital on the opportunity recognition process», Journal of Enterprising Culture, vol.14, N², pp.105-124.

Raisch S., Birkinshaw J., Probst G., et Tushman M. L. (2009), « Organizational Ambidexterity: 
International Journal of Social Science and Economic Research

ISSN: 2455-8834

Volume:06, Issue:04 "April 2021"

Balancing Exploitation and Exploration for Sustained Performance», Organization Science, vol.20, $\mathrm{N}^{\circ} 4$, pp.685-695.

Reagans R., et McEvily B. (2003), « Network Structure and Knowledge Transfer: The Effectsof Cohesion and Range», Administrative Science Quarterly, vol.48, N², p.240.

Rhee J., Park T., et Lee D. H. (2010), « Drivers of innovativeness and performance for innovative SMEs in South Korea: Mediation of learning orientation», Technovation, vol.30, $\mathrm{N}^{\circ} 1$, pp.65-75.

Rodrigo-Alarcon J., García-Villaverde P.M., et Ruiz-Ortega M.J. (2018), « From social capital to entrepreneurial orientation: The mediating role of dynamic capabilities», European Management Journal vol.36, pp.195-209.

Simsek Z. (2009), « Organizational Ambidexterity: Towards a Multilevel Understanding», Journal of Management Studies, vol.46, N4, pp.597-624.

Slater S. F., et Narver J. C. (1995), « Market Orientation and the Learning Organization», Journal of Marketing, vol.59, N³, p.63.

Stam W., Arzlanian S., et Elfring T. (2013), « Social capital of entrepreneurs and small firm performance: A meta-analysis of contextual and methodological moderators », Journal of Business Venturing.

Taylor A., et Helfat C. E. (2009), « Organizational Linkages for Surviving Technological Change: Complementary Assets, Middle Management, and Ambidexterity», Organization Science, vol.20, $\mathrm{N}^{\circ} 4$, pp.718-739.

Tsai W. (2001), « knowledge transfer in intraorganizational networks: effects of network position and absorptive capacity on business unit innovation and performance», Academy of Management Journal, vol.44, N5, pp.996-1004.

Tsai W., et Ghoshal S. (1998), « Social capital and value creation: the role of intrafirm networks », Academy of Management Journal, vol.41, N4, pp.464-476.

Urbach N., Ahlemann F., (2010), « Structural Equation Modeling in Information Systems Research using Partial Least Squares», Journal of Information Technology Theory and Application, vol.11, N², pp.5-40.

Wales, W. J., Kraus, S., Filser, M., Stöckmann, C., \& Covin, J. G. (2020). The status quo of 
International Journal of Social Science and Economic Research

ISSN: 2455-8834

Volume:06, Issue:04 "April 2021"

research on entrepreneurial orientation: Conversational landmarks and theoretical scaffolding. Journal of Business Research.

Wales, W. J. (2016). Entrepreneurial orientation: A review and synthesis of promising research directions. International Small Business Journal, 34(1), pp 357-383.

Wales W. J., Gupta V. K., et Mousa F-T. (2013), « Empirical research on entrepreneurial orientation: An assessment and suggestions for future research.», International Small Business Journal, vol.31, N4, pp.357-383.

Wang C. L., et Rafiq M. (2012). " Ambidextrous Organizational Culture, Contextual Ambidexterity and New Product Innovation: A Comparative Study of UK and Chinese Hightech Firms», British Journal of Management, vol.25, $\mathrm{N}^{\circ} 1$, pp.58-76

Wang C. L. (2008), « Entrepreneurial Orientation, Learning Orientation, and Firm Performance», Entrepreneurship Theory and Practice, vol.32, N4, pp.635-657

Wiklund J., et Shepherd D. (2003), « Knowledge-based resources, entrepreneurial orientation, and the performance of small and medium-sized businesses », Strategic Management Journal, vol.24, $\mathrm{N}^{\circ} 13$, pp.1307-1314;

Yalcinkaya G., Calantone R. J., et Griffith D. A. (2007). « An Examination of Exploration and Exploitation Capabilities: Implications for Product Innovation and Market Performance», Journal of International Marketing, vol.15, №4, pp.63-93.

Yli-Renko H., Autio E., et Sapienza H. J. (2001). « Social capital, knowledge acquisition, and knowledge exploitation in young technology-based firms», Strategic Management Journal, vol.22, pp.587-613.

Yusuf A. (2002). " Environmental uncertainty, the entrepreneurial orientation of business ventures and performance. », International Journal of Commerce and Management, vol.12, pp.83-103.

Zahra S. A., et Covin J. G. (1995). « Contextual influences on the corporate entrepreneurshipperformance relationship: A longitudinal analysis», Journal of Business Venturing, vol.10, $\mathrm{N}^{\circ} 1$, pp.43-58. 